\title{
Constraints to Effective Utilization of Information and Communication Technology Facilities in the Teaching and Learning Motor Vehicle Mechanic Trade
}

\author{
Abdulkadir, M; Ibrahim, D and S.A. Ma'aji (Ph.D) \\ Department of Industrial and Technology Education \\ Federal University of Technology, Minna
}

\begin{abstract}
This study was designed to identify the constraints to effective utilization of Information and Communication Technology Facilities in the teaching and learning of Motor Vehicle Mechanic trades in the Technical Colleges of Niger state. Four research questions were formulated to guide the study. A descriptive survey research design was employed for the study. The study was carried out in all the Technical Colleges of Niger State. A total of 498 respondents comprising 464 TCIII Motor Vehicle Mechanic students and 34 Motor Vehicle Mechanic teachers in all the technical colleges of Niger state were used as population for the study. A structured questionnaire developed by the researcher was used to collect data for the study. The instrument was validated by 3 lecturers in the Department of Industrial and Technology Education. Also a test-re-test method was used in determining the reliability of the instrument and Pearson Product Moment Correlation Coefficient was used to compute the reliability coefficient. The instrument has a reliability of 0.72. Mean statistic was used to analyze the data for answering research questions. The findings of the study among others revealed that: ICT facilities are not available in all the technical colleges for effective teaching and learning of motor vehicle mechanic trades, the teachers are not well trained on hoe to effectively utilized ICT facilities for teaching and learning of motor vehicle mechanic trades and that irregular power supply is affecting the effective utilization of ICT facilities in all the technical colleges of Niger State. Based on the findings it was recommended that government should ensure adequate provision of ICT facilities to all the technical colleges, teachers should be trained on how to effectively utilized ICT facilities in the teaching and learning of motor vehicle mechanic trades and there should be provision of electricity supply through an alternative other than public power supply so as to ensure effective utilization of ICT facilities in the teaching and learning of motor vehicle mechanic trade in all the technical colleges of Niger State.
\end{abstract}

Key words: Teaching and learning; ICT facilities; constraints, Utilization and Motor vehicle work.

\section{Introduction}

Teaching and learning are two activities that are geared towards the attainment of educational objectives. According to Ayeni \& Ogunbaru (2013) teaching and learning refers to an organized instructional process that is consciously geared towards transforming and developing learners' intellectual ability, skills, ethics and values to enable them function effectively and become self-reliant, and contribute positively to societal development. Teaching is a human undertaking whose aim is to help learner to learn. It is an interaction process between a teacher and a student under the teacher's guide (Abdulkadir, 2011). Learning on the other hand is a change in behaviour due to experience. Oguntonade (1998) sees learning as a process by which behaviour is initiated, modified or change.

However, in the context of this Study, teaching and learning is a joint description of teacher and student complimentary and interdependent classroom or workshop activities initiated, modified and directed towards assisting the learners to access knowledge, increase understanding, develop concepts and practice skills to achieve a set of learning objectives and specified standards within a formal school system. Furthermore, teaching and learning can as well be view as the way and means by which both teachers and students used ICT facilities to acquire new or modifying existing knowledge, behaviour, skills, values or preferences to enable them improve their performances or reorganize their thinking as a result of their active, intentional, motivational involvement in the process of knowledge construction, meaning making, and attitude development in the area of vocational technical education courses which motor vehicle mechanic is one.

Motor Vehicle Mechanic trade is one of the Technical vocational Education programmes which involves the acquisition of scientific knowledge in design, selection of materials, construction, operation and maintenance of motor vehicles. According to National Board for Technical Education (NBTE, 2001) Motor vehicle mechanics trade students are expected to, upon completion of this training, be able to: test, diagnose, service and repair any fault on conventional motor vehicle assemble main units and systems to the manufacturers' specifications. Abdulkadir (2011) explained that the objectives of the practical aspect of Motor 
Vehicle Mechanics at the technical college include the ability of motor vehicle craft trainees to be able to: test, rebuild and replace injector nozzles, dismantle and reassemble carburettor following appropriate procedure, replace major emission control components, diagnose all problems relating to steering, braking and suspension systems, among others. However, the attainment of these goals is largely dependent on the utilization of ICT faculties in the teaching and learning of motor vehicle mechanic trade.

ICT facilities can be described as the combination of items of equipment (hardware) and computer programmes (software) that that allow us to access, retrieve, store, organize, manipulate and present information by electronic means (Aleburu and Olusanya,2007). However, in the words of Ikuomola (2007) $\mathrm{ICT}_{\mathrm{s}}$ are computing and communications facilities and features that variously support teaching, learning and range of activities in education. He further stressed that ICT as an interdisciplinary domain focuses on providing students with tools to transform their learning and to enrich their environment. Olayanju(2007) sees ICT as all kinds of electronics that are used for broadcasting, telecommunication and all forms of computer mediated communication. He further explained that advances in ICT have its full advantage in all aspect of life. The use of ICT in technology education has brought many on-line packages which gives students greater control over what they learn and how they learn and that it also provides students with vast electronic learning capabilities (Abdulkadir,2011).

The use of ICT facilities in teaching and learning of vocational technical education which motor vehicle is an integral part of, offers the opportunity for both teachers and students to have access to libraries, data base of other institutions of learning, research institute, government agencies, stored files of technical and vocational education papers, studies, and reports. According to Abdulkadir (2011) the use of ICT facilities in vocational technical education has brought many on-line packages that give students greater control over what they learn and how they learn it. ICT facilities offers host different tools to demonstrate learning suitable for divergent and different intelligence (Aleburu \& Olusanya, 2007). Also in the words of Olayanju (2007) the use of ICT facilities allows teachers to focus their attention on the process rather than the products and at the same time serves as a diagnostic tool that allows teachers to identify learning trend and problems. All these imply that teaching and learning in vocational technical education are changing fast, not only in response to pressure from labour market but simply because of the challenges brought about as results of advancement in technology.

It is however sad to note that in spite of all these benefits offered as results of utilization of ICT facilities in the teaching and learning of vocational technical education courses which motor vehicle mechanic is one, most motor vehicle mechanic teachers still don't seems to utilize ICT facilities for instruction rather rely heavily on the traditional means of instruction. For instance, Abdulkadir, (2011) lamented that the new innovation of ICT facilities in teaching and learning in most technical colleges is still a dream yet to be realized as its utilization don't seems to be have been institutionalized by the technical teachers rather the traditional world of paper is still the order of the day. Buttressing these assertions Olayanju (2007) lamented that with these both teachers and students would not be exposed to enriching teaching and learning materials in the area of vocational technical education. It is not quite clear whether non-utilization that may be attributed to non availability of ICT facilities in technical college may be responsible for these. The problem of the study therefore, is to identify the constraints militating against effective utilization of ICT facilities for teaching and learning of motor vehicle mechanic trade in technical colleges of Niger State.

\section{Purpose of the Study}

The purpose of this study is to identify the constraints militating against effective utilization of ICT facilities for teaching and learning of motor vehicle mechanic trade in technical colleges of Niger State. Specifically, the study sought to:

1. Determine the availability of ICT facilities for use by the teachers in teaching and learning of motor vehicle mechanic trade.

2. Determine the extent to which teachers use ICT facilities for teaching and learning of motor vehicle mechanic trade.

3. Identify the constraints faced by the teachers in the use ICT facilities for teaching and learning of motor vehicle mechanic trade.

4. Identify the mechanisms that could be adopted by the teachers to enhance effective utilization of ICT facilities for teaching and learning of motor vehicle mechanic trade.

\section{Research Questions}

The following research questions were formulated to guide the study.

1. What are ICT facilities available for used by the teachers in teaching and learning of motor vehicle mechanic trade?

2. To what extend do the teachers used ICT facilities for teaching and learning of motor vehicle mechanic trade? 
3. What are the constraints faced by the teachers in the use of ICT facilities for teaching and learning of motor vehicle mechanic trade?

4. What are the mechanisms to be adopted by the teachers to enhance the effective utilization of ICT facilities in the teaching and learning of motor vehicle mechanic trade?

\section{Methodology}

This study was carried out in all the technical colleges in Niger State. A descriptive survey research was adopted for this study. A total of 498 respondents comprising 464 motor vehicle mechanic students and 34 motor vehicle mechanic teachers from all the technical colleges in Niger State formed the population for this study and the entire population was studied. A structured questionnaire developed by the researcher, named Information and Communication Technology Facilities Constraints Questionnaire (ICTFCQ) and validated by three experts from Industrial and Technology Education Department was used for data collection. The questionnaire items were assigned four points rating scale of: highly available (4), available (3), moderately available (2), and not available (1) for research question one. Highly extend (4), moderately extend (3), lowly extend (2), not at all (1) for research question two; While strongly agree (4), agree (3), disagree (2) and strongly disagree (1) for research questions three and four. 436 copies of questionnaire were distributed to teachers and students and 388 copies were dully filled by the respondents and retuned representing $88.9 \%$. Mean and Standard Deviation were the statistical tools used to analyze the data for answering research questions.

\section{Research Question 1}

\section{Results}

What are ICT facilities available for used by the teachers in teaching and learning of motor vehicle mechanic trade?

Table 1 Mean responses of teachers and students on the availability for used by the teachers in teaching and learning of motor vehicle mechanic trade $\mathrm{N}_{1}=34 \quad \mathrm{~N}_{1}=464$

\begin{tabular}{|l|l|l|l|l|l|}
\hline $\mathbf{S} / \mathbf{N o}$ & facilities & $\overline{X_{\mathbf{1}}}$ & $\overline{X_{\mathbf{2}}}$ & $\bar{X}_{\mathbf{t}}$ & Decision \\
\hline 1. & Internet & 2.04 & 2.94 & 2.17 & Not available \\
\hline 2. & Projector & 2.24 & 2.05 & 2.21 & Not available \\
\hline 3. & Fax Machine & 2.00 & 2.07 & 2.05 & Not available \\
\hline 4. & Telephone & 2.39 & 2.29 & 2.37 & Not available \\
\hline 5. & Computer Set & 2.47 & 2.35 & 2.41 & Not available \\
\hline 6. & Web Communication Technology & 2.11 & 2.09 & 2.08 & Not available \\
\hline 7. & Video Tapes & 2.04 & 2.94 & 2.17 & Not available \\
\hline 8. & Digital Camera & 2.02 & 2.01 & 2.15 & Not available \\
\hline 9. & Scanner & 2.40 & 2.50 & 2.45 & Not available \\
\hline 10. & Telegraph & 2.24 & 2.05 & 2.15 & Not available \\
\hline 11. & Radio & 2.31 & 2.29 & 2.30 & Not available \\
\hline 12. & Television & 2.71 & 2.00 & 2.34 & Not available \\
\hline 13. & Internet & 2.10 & 2.23 & 2.17 & Not available \\
\hline 14. & Microphone and Loudspeaker & 2.00 & 2.40 & 2.20 & Not available \\
\hline 15. & Flash Drive & 2.51 & 2.09 & 2.30 & Not available \\
\hline 16. & Printer & 1.00 & 1.34 & 2.34 & Not available \\
\hline 17. & GSM Mobile Phone & 2.71 & 2.56 & 2.64 & Available \\
\hline 18. & Analog modem & 2.01 & 2.00 & 2.01 & Not available \\
\hline 19 & Audio cassette tape & 2.46 & 2.11 & 2.29 & Not available \\
\hline 20. & CD-ROM and DVD & 2.02 & 2.01 & 2.15 & Not available \\
\hline
\end{tabular}

Key: $\mathrm{N}_{1}$ and $\mathrm{N}_{2}=$ No of Students and Teachers $\overline{X_{1}}=$ Mean responses of Students; $\overline{X_{2}}=$ Mean responses of Teachers $\overline{X_{t}}=$ Mean responses of all respondents.

Analysis in Table 1as revealed by the respondents indicates that majority of ICT facilities for teaching and learning of motor vehicle mechanic trades are not available in technical colleges in Niger State.

Research Question 2

To what extend do the teachers used ICT facilities for teaching and learning of motor vehicle mechanic trade? 
Table 2 Mean responses of teachers and students on the extend with which teachers used ICT facilities for teaching and learning of motor vehicle mechanic trade $\mathrm{N}_{1}=34 \quad \mathrm{~N}_{1}=464$

\begin{tabular}{|c|c|c|c|c|c|}
\hline S/No & facilities & $\overline{X_{1}}$ & $\bar{X}_{2}$ & $\overline{X_{\mathrm{t}}}$ & Decision \\
\hline 1. & Teachers often use microphones in teaching and learning. & 2.04 & 2.94 & 2.17 & Not at all \\
\hline 2. & Teachers do use Projectors in teaching and learning. & 2.24 & 2.05 & 2.21 & Not at all \\
\hline 3. & Teachers often use internet facilities. & 2.00 & 2.07 & 2.05 & Not at all \\
\hline 4. & Teachers do use computer in assessing the students. & 1.04 & 2.34 & 1.69 & Not at all \\
\hline 5. & Teachers often use internet in preparing lesson note. & 2.00 & 1.14 & 1.57 & Not at all \\
\hline 6. & $\begin{array}{l}\text { Teachers often use telegraph for sending messages over long } \\
\text { distances. }\end{array}$ & 2.42 & 2.32 & 2.37 & Not at all \\
\hline 7. & $\begin{array}{l}\text { Teachers do encourage students to use GSM for disseminating } \\
\text { information. }\end{array}$ & 2.33 & 1.12 & 1.73 & Not at all \\
\hline 8. & Teachers often make use computer for examination purposes. & 2.17 & 2.31 & 2.24 & Not at all \\
\hline 9. & Teachers do make use of radio in teaching and learning. & 2.14 & 2.01 & 2.08 & Not at all \\
\hline 10. & Teacher often use internet for the research work. & 1.22 & 2.31 & 1.77 & Not at all \\
\hline
\end{tabular}

Key: $\mathrm{N}_{1}$ and $\mathrm{N}_{2}=$ No of Students and Teachers $\overline{X_{1}}=$ Mean responses of Students; $\overline{X_{2}}=$ Mean responses of Teachers $\overline{X_{t}}=$ Mean responses of all respondents.

Analysis in Table 2 indicates that teachers are not using ICT facilities for teaching and learning of motor vehicle mechanic trades in technical colleges of Niger State as revealed by the respondents.

\section{Research Question 3}

What are the constraints faced by the teachers in the use of ICT facilities in teaching and learning of motor vehicle mechanic trade?

Table 3 Mean responses of teachers and students on the constraints faced by the teachers in the use ICT facilities for teaching and learning of motor vehicle mechanic trade $\mathrm{N}_{1}=34 \quad \mathrm{~N}_{1}=464$

\begin{tabular}{|l|l|l|l|l|l|}
\hline S/No & facilities & $\overline{X_{1}}$ & $\overline{X_{\mathbf{2}}}$ & $\bar{X}_{\mathbf{t}}$ & Decision \\
\hline 1. & Inadequate supply of computer hardware & 3.72 & 3.78 & 3.75 & Agreed \\
\hline 2. & Irregular power supply & 3.65 & 4.01 & 3.83 & Agreed \\
\hline 3. & Lack of training in the use of ICT facilities & 3.98 & 3.35 & 3.67 & Agreed \\
\hline 4. & Inadequate supply of computer software & 3.76 & 3.36 & 3.56 & Agreed \\
\hline 5. & Poor services of internet connectivity & 3.12 & 3.00 & 3.06 & Agreed \\
\hline 6. & Insufficient knowledge of how to use ICT facilities & 3.05 & 3.55 & 3.30 & Agreed \\
\hline 7. & Lack of financial support & 3.89 & 3.99 & 3.94 & Agreed \\
\hline 8. & Lack of competence & 3.00 & 3.59 & 3.30 & Agreed \\
\hline 9. & Lack of confidence & 3.78 & 3.90 & 3.84 & Agreed \\
\hline 10. & Resistance to changes & 3.78 & 3.65 & 3.72 & Agreed \\
\hline 11. & Lack of appropriate software & 3.89 & 3.88 & 3.89 & Agreed \\
\hline
\end{tabular}

Key: $\mathrm{N}_{1}$ and $\mathrm{N}_{2}=$ No of Students and Teachers $\overline{X_{1}}=$ Mean responses of Students; $\overline{X_{2}}=$ Mean responses of Teachers $\overline{X_{t}}=$ Mean responses of all respondents.

Analysis in Table 3 revealed that respondents agreed with all items as constraints faced by the teachers in the use of ICT facilities for teaching and learning of motor vehicle mechanic trades in technical colleges of Niger State.

\section{Research Question 4}

What are the mechanisms to be adopted by the teachers to enhance the effective utilization of ICT facilities in the teaching and learning of motor vehicle mechanic trade? 
Table 4 Mean responses of teachers and students on the mechanisms to be adopted by the teachers to enhance the effective utilization of ICT facilities for teaching and learning of motor vehicle mechanic $\operatorname{tradeN}_{1}=34 \quad \mathrm{~N}_{1}=464$

\begin{tabular}{|c|c|c|c|c|c|}
\hline S/No & facilities & $\bar{X}_{1}$ & $\bar{X}_{2}$ & $\bar{X}_{\mathrm{t}}$ & Decision \\
\hline 1. & Provision of alternative of electricity supply & 3.61 & 3.33 & 3.47 & Agreed \\
\hline 2. & Periodic organization of workshop and seminars on ICT & 3.02 & 3.45 & 3.24 & Agreed \\
\hline 3. & Adequate provision of ICT facilities & 3.76 & 3.11 & 3.44 & Agreed \\
\hline 4. & Training of ICT maintenance personnel in school & 3.39 & 3.79 & 3.59 & Agreed \\
\hline 5. & Better management of available ICT facilities & 3.01 & 3.40 & 3.21 & Agreed \\
\hline 6. & Encouraging and support teachers and students to own personnel computers & 3.37 & 3.88 & 3.63 & Agreed \\
\hline 7. & Training of teacher on the use of ICT facilities & 3.77 & 3.12 & 3.45 & Agreed \\
\hline
\end{tabular}

Key: $\mathrm{N}_{1}$ and $\mathrm{N}_{2}=$ No of Students and Teachers $\overline{X_{1}}=$ Mean responses of Students; $\overline{X_{2}}=$ Mean responses of Teachers $\overline{X_{t}}=$ Mean responses of all respondents.

Analysis in Table 4 revealed that respondents agreed with all items as mechanisms to be adopted by the teachers to enhance the effective utilization of ICT facilities for teaching and learning of motor vehicle mechanic trades in technical colleges of Niger State.

\section{Discussion of Results}

Analysis in Table 1as revealed by the respondents indicates that majority of ICT facilities for teaching and learning of motor vehicle mechanic trades are not available in technical colleges in Niger State. This is in consonance with the views of Ede \& Adio (2010) who lamented that in spite of steps taken by Nigeria government to embrace the use of ICT facilities in education, ICT facilities has not been made available in almost $90 \%$ of Nigeria schools and colleges. Also corroborating this assertion Okwudishu (2005) explained that non availability of ICT facilities in schools hampers teacher's use of ICTs. The non availability of ICT facilities has put many students at disadvantage in practical application of procedure involved in learning ICT, while teachers involved face the challenges of not being able to give most students the desire individual attention to explain difficult concept to concretize their knowledge and such predicament narrow the opportunity available to stimulate students for further usage of ICT facilities for independent learning beyond the normal classroom interaction (Adeyemo, 2010).

Analysis in Table 2 indicates that teachers are not using ICT facilities for teaching and learning of motor vehicle mechanic trades in technical colleges of Niger State as revealed by the respondents. This is in-line with the views of Ayeni \& Ogunbaru (2013) who stressed that in spite of the benefit of ICTs in education, most teachers have not taken the advantages in their classroom teaching and professional development. Ayeni \& Ogunbaru (2013) further asserted that the reason adduced for non utilization of ICTs in teaching-learning process were inadequacy of ICT facilities for the teeming population of teachers and students who needed them. The use of ICTs has not been institutionalized in our schools and colleges (Aleburu, 2005). The new innovation of ICTs in teaching-learning process is still a dream yet to be realized in most technical colleges, thus traditional world of paper is still the order of the day (Abdulkadir, 2011).

Analysis in Table 3 revealed that respondents agreed with all items as constraints faced by the teachers in the use of ICT facilities for teaching and learning of motor vehicle mechanic trades in technical colleges of Niger State. This corroborate with the views of Ohanu (2010) who stressed that teacher development is a major challenge for the use of ICT facilities in teaching and learning, this according to Ohanu (2010) most teachers information technologies are both exhilarating in their possibilities and daunting in the uncertainty created by the speed of advancement in technology. Lack of confident and competence as well as resistance to change and lack of appropriate software are constraints to the utilization of information and technology in teaching and learning of vocational technical education courses which motor vehicle mechanic is one (Allen, Walker \& Morehead, 1999). Umanadi (2011) lamented that very low power supply, unstable and its non-availability in most part of the country also hinder the successful utilization of ICT facilities in Nigeria schools.

Analysis in Table 3 revealed that respondents agreed with all items as mechanisms to be adopted by the teachers to enhance the effective utilization of ICT facilities for teaching and learning of motor vehicle mechanic trades in technical colleges of Niger State. This is in agreement with the vies of Ugwoke, (2011) who identified the following mechanisms to be adopted for the effective utilization of ICT facilities to include capacity building program for technical staff on ICT maintenance, provision of alternative sources of electricity supply, increasing the time allocated for ICT training, instructions and practice, connectivity of school to the internet, school partnership with relevant professional and corporate bodies for technical support, periodic organization of workshops, seminars and conferences. 


\section{Conclusion}

Evident from this study formed the basis for the following conclusion: in spite of the benefits of ICTs in education, most teachers are not utilizing it in the teaching and learning of motor vehicle mechanic trades at technical college level this is as a result of non availability of ICT facilities and lack of adoption of effective mechanisms that would enhanced effective utilization of ICT facilities in the teaching and learning of motor vehicle mechanic trades at technical college level. Nevertheless, if the findings of this study are effectively utilized teaching and learning of motor vehicle mechanic trades would be greatly improved which will in turn lead to production highly skilled manpower for the nation.

\section{Recommendations}

1. Government should ensure adequate provision of ICT facilities in all the technical colleges of Niger State for effective teaching and learning of motor vehicle mechanic trades.

2. Teachers should be train on the effective utilization of ICTs in the teaching and learning of motor vehicle mechanic trades by the experts.

3. Teachers should on regular basis be exposed to mechanisms for effective utilization of ICTs in the teaching and learning of motor vehicle mechanic trades through periodic organization of workshop and seminar on ICT.

4. There should be provision of electricity supply through an alternative other than public power supply.

\section{References}

[1]. Abdulkadir, M.(2011).Improving teaching and learning of Motor Vehicle Mechanic Trades through the use of Information and Communication Technology at Technical College level. ATBU Journal of Technology and Educational Research ( JOTER). 4(1) 203-213.

[2]. Adeyemo, A. A. (2010). The impact of information and communication technology on teaching and learning of physics. International Journal of Educational Research and Technology, 1(2), 6-8.

[3]. Aleburu,J.O. and Olusanya,S.92007) Use of ICT to Enhance Teaching and Learning of Technical and Vocational Trades in Primary Schools. In S.M Yalams, B. Bukar S. A. Adebayo, S.T.Puyate and A.K. Onwuchekwa (Eds). Technical and Vocational Education: A challenge to the Nigeria Educational Reform Agenda. Proceedings of $20^{\text {th }}$ Annual National Conference of Nigerian Association of Teachers of Technology held at Kaduna Polytechnics, Kaduna. $5^{\text {th }}-9^{\text {th }}$ November, 2007.397-413.

[4]. Allen, J. Walker, M \& Morehead, C. (1999). Technology in secondary career and technical education: Issues in new millennium. Workforce Education Forum 28 (1) 1-13.

[5]. Ayeni, A.J. \& Ogunbaru, M. (2011). Effective utilization and maintenance of ICT facilities for quality teaching and learning in Secondary Schools in Ondo State. International of Journal of Research in Educational technology.1(1) 1-13.

[6]. Ikumola,A.J.(2007) Enhancing Technical and Vocational Education for Sustainable Development Through Information and Communication. In S.M Yalams, B. Bukar S. A. Adebayo, S.T.Puyate and A.K. Onwuchekwa (Eds). Technical and Vocational Education: A challenge to the Nigeria Educational Reform Agenda. Proceedings of $20^{\text {th }}$ Annual National Conference of Nigerian Association of Teachers of Technology held at Kaduna Polytechnics, Kaduna. $5^{\text {th }}-9^{\text {th }}$ November, 2007.149-155.

[7]. National Board for Technical Education (2001). National Technical Certificate Programme in Mechanical Engineering Craft Practice Curriculum. Kaduna: NBTE/Layon.

[8]. Oguntonade, C.J. (1998). Promoting teaching and learning of mathematics in higher education. A paper presented at the UNESCO workshop on teaching and learning in higher education. University of Ibadan, Nigeria.

[9]. Ohanu, I.B. (2012). Challenges and prospects of using information and communication technology in teaching and learning of Electrical/Electronics in Technical Colleges in Anambra State. International Journal of Educational Research (INJER). University of Nigeria, Nsukka. 11(1) 154-161.

[10]. Okwudishu, C.H. (2005). Awareness and use of information and communication technology (ICT) among village secondary school teachers in Aniocha South Local Government Area of Delta State. Abraka: Delta State University. Unpublished B.Sc.(LIS project).

[11]. Olanyanju,T, (2007) Vocational and Technical Education Reform Through the use of Information and Technology. In S.M Yalams, B. Bukar S. A. Adebayo, S.T.Puyate and A.K. Onwuchekwa (Eds). Technical and Vocational Education: A challenge to the Nigeria Educational Reform Agenda. Proceedings of $20^{\text {th }}$ Annual National Conference of Nigerian Association of Teachers of Technology held at Kaduna Polytechnics, Kaduna. $5^{\text {th }}-9^{\text {th }}$ November, 2007. 572-578.

[12]. Ugwoke, E. O. (2011). Effective utilization of ICT for repositioning business education program in tertiary institutions in Nigeria for national development. International Journal of Education Research, 11(1), 202-214.

[13]. Umunadi, E.K. (2011). Perception of technical education students on the role of ICT in general studies programme in University education. International Journal of Academic Research in Business and Social Sciences. 1(3) 190-206. 